\title{
Anuário Antropológico
}

v.47 n. 1 | 2022

2022/v.47 n.1

\section{Revoltas do povo da BR-163 contra crises da ambientalização do governo}

BR-163 people's revolts against crises of the government's environmentalization

\section{Renata Barbosa Lacerda}

\section{(2) OpenEdition}

Journals

Edição electrónica

URL: https://journals.openedition.org/aa/9306

DOI: $10.4000 /$ aa. 9306

ISSN: 2357-738X

Editora

Programa de Pós-Graduação em Antropologia Social (UnB)

\section{Edição impressa}

Paginação: 19-43

ISSN: 0102-4302

\section{Refêrencia eletrónica}

Renata Barbosa Lacerda, «Revoltas do povo da BR-163 contra crises da ambientalização do governo», Anuário Antropológico [Online], v.47 n. 1 | 2022, posto online no dia 31 janeiro 2022, consultado o 22 julho 2022. URL: http://journals.openedition.org/aa/9306 ; DOI: https://doi.org/10.4000/aa.9306

\section{(c) (i) (9)}

Creative Commons - Atribuição-NãoComercial-SemDerivações 4.0 Internacional - CC BY-NC-ND 4.0 https://creativecommons.org/licenses/by-nc-nd/4.0/ 


\section{Anuário Antropológico}

v.47 n.1 | 2022

2022/v.47 n.1

\section{Revoltas do povo da BR-163 frente às crises da ambientalização do governo}

$B R$-163 people's revolts: crises of the government's environmentalization

\section{Renata Lacerda}

\section{Q OpenEdition \\ Journals}

\section{Edição electrônica}

URL: http://journals.openedition.org/aa/9306

DOI: $10.4000 / a a .9306$

ISSN: 2357-738X

\section{Editora}

Programa de Pós-Graduação em Antropologia Social (UnB)

Referência eletrônica

Renata Lacerda, «Revoltas do povo da BR-163 frente às crises da ambientalização do governo»,

Anuário Antropológico [Online], v.47 n.1 | 2022. URL: http://journals.openedition.org/aa/9306 ; DOI:

https://doi.org/10.4000/aa.9306

\section{(c) (i) $(9)$}

Anuário Antropológico is licensed under a Creative Commons. Atribuição-SemDerivações-SemDerivados CC BY-NC-ND 


\title{
Revoltas do povo da BR-163 frente às crises da ambientalização do governo
}

\author{
BR-163 people's revolts: crises of the government's environmentalization \\ DOI: https://doi.org/10.4000/aa.9306
}

\begin{abstract}
Renata Lacerda
Universidade Federal do Rio de Janeiro, Museu Nacional - Brasil

Doutoranda no Programa de Pós-Graduação em Antropologia Social, Museu Nacional, Universidade Federal do Rio de Janeiro (PPGAS/MN/UFRJ), Rio de Janeiro, RJ, Brasil. Pesquisadora do Núcleo de Antropologia da Política (NuAP) e do Núcleo de Estudos sobre Amazônia Contemporânea (NUAMA/UERJ).
\end{abstract}

Analiso como crises foram tecidas em uma metanarrativa que justificava as revoltas daqueles que se apresentavam como povo de Novo Progresso e/ou da região da BR-163 (Oeste do Pará, Brasil). Ainda que com disputas internas, produtores rurais, agricultores familiares, garimpeiros, empresários, comerciantes, madeireiros e indígenas se aliaram eventualmente em ações coletivas a partir da demarcação da Terra Indígena Baú e da implantação de políticas de mitigação dos impactos da pavimentação da rodovia BR-163 (Cuiabá-Santarém). Argumento que essas mobilizações conjuntas foram fruto da construção de comunidades morais-afetivas que compartilhavam memórias acerca das injustiças do governo federal desde a abertura da rodovia pela ditadura militar. Nessas memórias, que compõem o conhecimento da região, denunciavam a reprodução da precariedade e de crises pelo Estado por meio de narrativas de abandono, sacrifícios, sofrimentos, humilhações, desrespeito a direitos, lutas, amor à terra e ameaças, como invasões. Baseio-me em trabalhos de campo no município de Novo Progresso, bem como em mídias sociais, reportagens da imprensa, documentos governamentais e publicações escritas por moradores da região.

Mobilização social; conflitos socioambientais; ambientalização; memória; BR-163 paraense.
I analyze how crises were woven into a metanarrative that justified the revolts of those who presented themselves as the people from Novo Progresso and/or from the BR-163 region (West of Pará, Brazil). Despite internal disputes, rural producers, gold miners, businessmen, loggers, small settlers and indigenous people eventually joined forces in collective actions since the demarcation of the Baú Indigenous Land and the implementation of policies to mitigate the impacts of paving the BR163 (Cuiabá-Santarém). I argue that these joint mobilizations were the result of the construction of moral-affective communities that shared memories about the injustices of the federal government since the opening of the highway by the military dictatorship. In these memories, which make up the knowledge of the region, they condemned the reproduction of precariousness and crises by the State through narratives of abandonment, sacrifices, suffering, humiliation, disrespect for rights, struggles, love for the land and threats such as invasions. I draw on fieldwork in the municipality of Novo Progresso, as well as social media, press reports, government documents and publications written by residents of the region.

Social mobilization; socio-environmental conflicts; environmentalization; memory; BR-163 from Pará. 


\section{Introdução}

A sedição [revolta] é a resposta de um grupo, comunidade ou classe a uma crise.

Edward Palmer Thompson
"A crise paralisou tudo, acabou com o movimento da cidade, muitos foram embora". "O governo nos abandonou e voltou só para reprimir". "Se o governo não resolver o problema que criou, vamos fechar a BR". "O conflito é com o governo". Afirmações como essas se repetiam nos trabalhos de campo que realizei em Novo Progresso, município cortado rodovia BR-163 (Cuiabá-Santarém) no Oeste do Pará, fronteira com Mato Grosso. Também podem ser encontradas em publicações sobre a região em que o município é inserido, cujas principais referências para seus habitantes são a BR-163 e a bacia do Tapajós.

Pessoas e famílias que viriam a constituir o povo de Novo Progresso e da região da BR-163 se valorizavam por permanecerem em locais abandonados, à beira de uma rodovia central para a nação e, posteriormente, para o chamado agronegócio brasileiro. Lembravam-se de lutas e sofrimentos que datavam da abertura da Cuiabá-Santarém pelo Programa de Integração Nacional (PIN) da ditadura militar, nos anos $1970^{1}$. Rememoravam que foi nesse contexto que chegaram os pioneiros para colonizarem a Amazônia. Ao contarem as crises dos ciclos de ocupação e de vocações econômicas, reelaboravam memórias e expectativas acerca do futuro de suas famílias e da BR-163.

Ao longo desses ciclos muitas vezes coexistentes, formaram diferentes classes organizadas em associações, sindicatos e cooperativas: produtores rurais (pequenos, médios e grandes); garimpeiros (desde empresários e donos de garimpo a trabalhadores); comerciantes e empresários; trabalhadores rurais e agricultores familiares; madeireiros (sobretudo donos de madeireiras). Essas classes e suas divisões internas apresentaram tanto disputas quanto parcerias entre si na promoção do progresso que nomeou o município. Nesse processo, povos indígenas como os Kayapó enfrentaram sucessivas ameaças à manutenção e demarcação de seus territórios por parte dos brancos que chegaram com a rodovia ${ }^{2}$.

Contudo, alianças e acordos entre segmentos dessas classes e povos indígenas foram manifestados publicamente em algumas ações coletivas. Entre elas, os bloqueios da BR-163 e as ameaças de bloqueio surgiram e se consolidaram como uma das principais formas de ação coletiva nessa região desde $2003^{3}$. Foi principalmente a partir desse ano, com o governo do presidente Luiz Inácio Lula da Silva, que a aguardada pavimentação da rodovia avançou no trecho paraense, fomentando o escoamento do agronegócio do Mato Grosso para o porto de Santarém (PA). Com isso, fechar a $B R$ passou a ser uma forma de pressionar o governo federal a solucionar seus problemas.

Todas as ações coletivas conjuntas eram pautadas pela BR-163. Seja pela promessa de progresso da região através da abertura e exploração da terra e do subsolo
1 Em itálico se encontram termos êmicos relevantes para a presente análise.

2 Ver: Campbell (2015), Castro, Monteiro e Castro (2004), Correa, Castro e Nascimento (2013), EIA BR-163 (2002), Lacerda (2015), Tarca (2014), Torres, Doblas e Alarcon (2017). 3 Em 2002, pequenos agricultores realizaram uma série de protestos, inclusive com bloqueio da BR-163 e ocupações de fazendas abandonadas, para demandar terra em Castelo dos Sonhos, distrito de Altamira vizinho de Novo Progresso (Campbell, 2015). Conheciam essa ação por meio de povos indígenas de outros locais da Amazônia (Idem, 2012). Contudo, na memória daqueles com quem conversei, inclusive lideranças indígenas, os bloqueios da BR-163 realizados na região são remetidos a 2003. 
- sonhos mobilizados sobretudo pela construção de rodovias e pela propaganda militar para atrair determinadas famílias e empresas para a Amazônia ${ }^{4}$. Seja pelas condições em que a pavimentação avançou, que geraram compensações ambientais.

Foram as condições ambientais à chegada do asfalto que levaram à pior crise lembrada pelo povo da BR-163, haja vista que frearam os sonhos que moveram a colonização da Amazônia. Elas decorreram do Plano BR-163 Sustentável, elaborado pelo governo federal em resposta a organizações da sociedade civil, que reivindicavam o combate aos riscos socioambientais da pavimentação.

Argumento que diferentes versões sobre essa crise evidenciam um processo de "comunização" (Bemerguy 2019) afetivo-moral em torno da BR-163, em que sentimentos como sofrimento e humilhação foram motores de suas indignações, gerando revoltas. Com isso, sujeitos que se diferenciavam entre si se reuniram na luta por causas regionais comuns (Ibid.). E/ou se aproximaram em manifestações a partir de lutas diferentes, construídas como não mutuamente excludentes por terem o governo como antagonista comum (Lacerda 2019).

Assim, a partir da crise, reconstruíram suas memórias em uma metanarrativa por meio da costura de sofrimentos e dores particulares em conhecimentos locais sobre injustiças do Estado, externalizado enquanto adversário (Das, 1995). Nessa metanarrativa, esqueceram e lembraram-se de determinados eventos do passado para enfatizar a construção da região (povo da BR) e do município (povo de Novo Progresso) ${ }^{5}$.

Cabe mencionar que não presenciei os protestos que analiso neste trabalho. Baseio-me nos relatos que obtive desses eventos, tanto nos trabalhos de campo no município de Novo Progresso, de 2013 a 2018, quanto em publicações e conversas pessoais nas mídias sociais, reportagens da imprensa, discursos de representantes em instituições públicas e documentos governamentais. Conversei com pessoas que se autodenominavam produtores rurais, empresários, assentados agricultores, madeireiros, garimpeiros e três lideranças indígenas Kayapó ${ }^{6}$. Apresentei-me como pesquisadora interessada na história e problemas locais.

Apesar de desconfianças sobre minhas intenções por ser branca do Sudeste - traço comum a jornalistas, ambientalistas e agentes governamentais -, muitos queriam me transmitir o conhecimento da região. Afinal, entendiam que os problemas das políticas públicas seriam decorrentes da falta desse conhecimento, que costurava biografias particulares à metanarrativa. Comentavam que um dos efeitos positivos dos bloqueios de rodovia foi a presença de alguém como eu para testemunhar e compartilhar seu conhecimento para fora.

No primeiro item, destaco como a crise afetou narrativas sobre a colonização. Nos itens seguintes, detalho medidas e efeitos das políticas que geraram diferentes sentidos de crises: declínio das vocações econômicas, de desemprego, moral-existencial. Por fim, analiso como os bloqueios da BR-163 expressaram revoltas em que aderiam e se opunham a governos, narrativas históricas, grupos sociais e projetos de desenvolvimento.
4 Ver: Bemerguy (2021), Campbell (2012) e Tarca (2014) para a BR-163. Ver Cordeiro (2018) para a BR-364 e Galuch (2019) para a Transamazônica (BR-230). Tedesco (2015) aborda como a construção da BR-163 e da Transamazônica ocasionou o crescimento de Itaituba como referência dos garimpos já existentes no Tapajós.

5 Baseio-me na noção de comunidades imaginadas de Anderson (2008) para pensar no papel criativo da violência e de emoções como o sofrimento (Das 1995) na coprodução de comunidades e pessoas imaginadas pela memória (Lambek, 2016), bem como os cruzamentos entre cognição e engajamentos morais-afetivos na produção de identidades coletivas (Jasper 2018). Já a noção de comunidades morais de Bailey (1971) contribui para pensar as reputações em jogo nas ações coletivas.

6 Identificam-se como Mebengôkré, do povo Mekrãgnoti. 


\section{Histórias de colonização: ciclos e crises}

Fontes orais e escritas sobre a história da região e de Novo Progresso destacam a rodovia Cuiabá-Santarém como um "corredor de sonhos" que fomentou a chegada de famílias reconhecidas como pioneiras quando só existia mato - alguns mencionam ainda que havia indios que causavam medo. Embora também houvesse muitas famílias vindas do Nordeste, a maioria daquelas lembradas pelo pioneirismo eram de colonos brancos vindos do Sul - alguns parando antes no Centro-Oeste -, não raro de ascendência europeia. Eram frequentemente valorizados por terem dado seu sangue e suor pela terra que vieram a amar. Ressaltavam assim seus sacrifícios para segurarem a Amazônia frente a ameaça da invasão por estrangeiros ("integrar para não entregar"), seguindo incentivos do governo que, em seguida, teria lhes abandonado ${ }^{7}$.

Os momentos em que foram redigidas as memórias de colonização revelam mudanças nas tonalidades e personagens dessa história. Três livros escritos por moradores de Novo Progresso registraram perspectivas particulares de diferentes períodos do local: Gertrudes Oravec (2008), pioneira sulista descendente de alemães; Zé Coruja (2004), que chegou nos anos 1990, vindo de Redenção (PA); Sara Schneider e Raquel Fortes (2011), pioneiras sulistas 8

Escrito de 1989 a 1994, a "Saga dos pioneiros do Pará" de Oravec é um retrato do que consideram ser o início da história de Novo Progresso. Apesar de escrever no fim do que seria conhecido como primeiro ciclo do ouro (1983-1991), Gertrudes não deu centralidade a esse tema. Falava em crise em termos dos sacrifícios e dificuldades enfrentados por pioneiros, sendo importante a solidariedade da brava gente progressense para ficar e acreditar na região, apesar do isolamento decorrente do estado precário da BR-163. Valorizou o trabalho dos colonos na agricultura, pecuária e abertura de comércios e serrarias. Associou os garimpeiros aos nordestinos, retratados como homens sem família, que desperdiçavam ouro e causavam medo à população. Retratou o ouro pela atração de perigos e grileiros/invasores vindos de fora.

Já “Novo Progresso - passado, presente e futuro", de Zé Coruja, foi redigido de 1997 a 2004, período conhecido como febre do ouro e da madeira, com o objetivo de atrair mais gente para o município. Não falou sobre a crise do ouro de 1991 e demonstrou otimismo com o progresso da cidade e da região do Tapajós. Enfatizou os buracos e atoleiros da BR-163, mas acreditava na iminência da sua pavimentação e da emancipação do Estado do Tapajós ${ }^{9}$, que tornaria Novo Progresso um grande produtor e exportador de grãos e carnes. Elogiou a valentia dos pioneiros que amam a terra, mas reforçou o papel de famílias de toda parte do Brasil. Não valorizou apenas o trabalho de produtores rurais, mas também de madeireiros, pilotos de avião, profissionais liberais, religiosos, investidores e políticos. Descreveu o povo progressense como honesto e trabalhador. Quem chegasse depois, como sua família, se tornaria progressense ao conhecer nosso amor e lutaria pelas causas paraenses (Ibid., 5).

“A história de Novo Progresso”, escrito em 2005 e 2006 por Sara e Raquel, re-
7 Ver Lacerda (2021) para o pioneirismo em Novo Progresso, Almeida (2021) para Mato Grosso e Cordeiro (2018) para Rondônia.

8 Apesar do uso do termo pioneiras no feminino, cabe reiterar que os pioneiros mais reconhecidos publicamente eram homens. Mas Sara, Raquel e Gertrudes se diziam pioneiras. 
toma a narrativa de Gertrudes, como a exaltação do pioneirismo, conflitos de colonos com garimpeiros e invasores, sofrimento e precariedade. As sulistas descreveram que, "com o abandono do Exército, ou seja, do Governo, da BR 163 [em 1979] iniciou-se o período mais humilhante para o povo em função da situação deplorável que chegou a estrada na década de 80" (Schneider e Fortes 2011, 53). As doenças ocasionaram sofrimento ao povo. As famílias sulistas que resistiram dependeram da solidariedade frente a circunstâncias humilhantes, em que não podiam trabalhar na terra conforme o governo havia prometido, pois não conseguiam escoar suas produções agrícolas. Outra promessa não cumprida foi a titulação definitiva das terras abertas. A culpa recaía no Incra (Instituto Nacional de Colonização e Reforma Agrária), que reconheceu o direito de alguns colonos (após o desmate de $50 \%$ da área) com documentos provisórios de aptidão à posse. $\mathrm{Na}$ época, esses documentos davam direito a financiamento em bancos.

Ao fim, Sara e Raquel se queixaram que, em meio às várias mortes, acidentes, doenças, falta de atendimento médico, conflitos com garimpeiros e grileiros, os "cidadãos são feridos na sua dignidade humana até perecerem pelo descaso" de políticos e pela justiça ineficaz (Ibid., 123). Ademais, indicaram a dúvida e a ansiedade quanto ao futuro acerca das medidas ambientais do governo federal em 2004 e 2005, que "deixou a todos sem saber como agir" (Ibid., 87). Como uma pioneira refletiu: "Toda mudança de ciclo há um período de crise e nós tivemos uma crise muito feia, porque o ouro acabou [1991], as pessoas foram embora. [...] agora temos esta crise da madeira [...] que eu acredito que vai demorar passar, mas vai passar" (Ibid., 84).

Muitos colonos me contaram que a mudança de suas famílias para Novo Progresso havia decorrido de crises (financeiras, conflitos, construção de barragens, doenças, mortes) que ameaçaram suas terras e/ou mudaram arranjos familiares. Por isso, decidiram ir embora do Sul, Mato Grosso e Rondônia. Alguns, como Gertrudes, contaram que seus antepassados haviam fugido de guerras na Europa. Rememoravam assim ciclos de pioneirismo, em que seu valor identitário era pautado pelo espírito colonizador, que segue em frente em meio ao abandono governamental ${ }^{10}$, sobretudo ao se depararem com crises. Como Thompson (1998, 206) indicou, agrupamentos sociais respondem a crises por meio de variadas ações coletivas, da "migração de aldeias inteiras" às revoltas.

Logo, uma das comprovações das variadas crises era o fato de muitos moradores irem embora. Isso ocorreu em 1991, quando o ex-presidente Fernando Collor de Mello (1990-1992) foi responsabilizado por "mudanças governamentais na economia nacional" que levaram à crise do primeiro ciclo desse metal (Schneider e Fortes 2011, 65), bem como à crise financeira em todo o país (Oravec 2008). Contudo, os impactos dessa crise do ouro na região da BR-163 foram amenizados pelo:

a) ciclo da pecuária, alternativa mais segura que a agricultura, dada a intrafegabilidade da BR-163;

b) emancipação política do município de Novo Progresso em 1993, desmembrado de Itaituba;
10 Ver Schumann et al. (2015) e Seyferth (1992). 
c) ciclo da madeira, iniciado na segunda metade dos anos 1990;

d) um novo ciclo do ouro na virada do século.

Foram as febres da madeira e do ouro que motivaram a chegada de milhares de famílias e o otimismo do livro de Zé Coruja. Nos anos seguintes à crise de 2004, Zé Coruja e sua esposa foram embora, junto com cerca de $40 \%$ da população municipal ${ }^{11}$.

\section{Ambientalização: crise das vocações}

Desde então, grande parte dos habitantes não só do município de Novo Progresso, como dos povoados vizinhos cortados pela rodovia Cuiabá-Santarém nos municípios de Altamira e Itaituba ${ }^{12}$, relata uma grande crise que estagnou a região da BR-163, tanto em termos da crescente circulação de riqueza, coisas e famílias, quanto dos ideais de desenvolvimento e progresso. Para as classes dos produtores rurais, madeireiros, garimpeiros e empresários progressenses, o Plano BR-163 Sustentável mudou as regras do jogo de acesso às terras públicas e aos recursos florestais e minerais na região. A responsabilidade desse processo foi atribuída ao ex-presidente Lula (2003-2010) e à sua ministra do Meio Ambiente (MMA), Marina Silva.

O Plano previa "fortalecer a presença do Estado na região", delimitada como área de influência da BR-163, abrangendo Amazonas, Mato Grosso e Pará (GTI 2005, 5). Através de um Grupo de Trabalho Interministerial, que apresentou disputas internas ${ }^{13}$, delineou medidas para mitigar impactos socioambientais da pavimentação da BR-163, especialmente o desmatamento e a grilagem. Em linhas gerais, instituiu o aumento da fiscalização ambiental pelo Ibama (Instituto Brasileiro do Meio Ambiente e dos Recursos Naturais Renováveis) e a destinação de terras públicas federais. Para isso, foi criado um mosaico de unidades de conservação (UCs) e dezenas de assentamentos rurais sustentáveis na região. Consoante o processo de ambientalização (Leite Lopes 2006), preconizava mecanismos de participação social e parcerias com governos estaduais e municipais. Ademais, sua implantação previa a articulação com planos direcionados para a Amazônia ${ }^{14}$ e com o processo de licenciamento ambiental da BR-163 (EIA BR-163), que destinava compensações a povos indígenas afetados pela pavimentação da rodovia, pelo Componente Indígena do Programa Básico Ambiental (PBA-CI).

Nos relatos de moradores, a medida do Plano BR-163 Sustentável que anunciou a crise foi a Portaria Conjunta ${ }^{\circ}$ 10/2004 do extinto Ministério do Desenvolvimento Agrário (MDA) e Incra ${ }^{15}$, que invalidou direitos atrelados a documentos cadastrais expedidos pelo Incra em terras públicas federais na Amazônia Legal. Até então, esses documentos de aptidão à posse eram suficientes para a aprovação de planos de manejo florestal no Ibama. Com a Portaria de 2004, os planos de manejo já existentes foram suspensos e o título definitivo se tornou necessário para a aprovação de novas autorizações de exploração florestal. Visto que ninguém possuía titulação no município, nem de posse nem de propriedade privada, isso foi vivenciado como perda dos direitos vigentes de acesso à terra e à floresta.
11 Segundo o IBGE (Instituto Brasileiro de Geografia e Estatística), Novo Progresso tinha cerca de 5 mil habitantes em 1991, 15 mil habitantes em 1996, 25 mil em 2000, mais de 35 mil em 2004, 21 mil em 2007.

12 Altamira é o maior município do Brasil; apenas uma pequena área corta a BR-163 a oeste, nos distritos de Castelo dos Sonhos e Cachoeira da Serra, a mais de mil quilômetros de distância da sede municipal. Itaituba fica a norte de Novo Progresso e é cruzado pela BR-163 e pela Transamazônica.

13 Ministérios como o Ministério da Agricultura, Pecuária e Abastecimento (MAPA) viam o Plano como entrave para a expansão do agronegócio na região. Já o MMA defendia o Plano integralmente ao priorizar a ideia de sustentabilidade (Araújo 2007, Leão 2017).

14 Plano de Ação para Prevenção e Controle do Desmatamento na Amazônia Legal (PPCDAm) e o Plano Amazônia Sustentável (PAS). Ver: Araújo (2007) e Lacerda (2015).

15 O MDA foi extinto em 2016 por Michel Temer. Em 2020, Jair Bolsonaro transferiu o Incra para o MAPA. 
Ao lado disso, reclamavam que reivindicações antigas de moradores, como regularização fundiária, serviços públicos de saúde e educação, energia elétrica fora da cidade e finalização da pavimentação da BR-163 continuavam sendo promessas. Assim, ao buscar se fazer "presente na região", o governo ambientalizado continuou a ser percebido como ausente em termos de direitos morais e legais, mas, ao mesmo tempo, repressor na exigência dos novos deveres.

\section{0 governo criou florestas}

Além da Portaria de 2004, muitos atribuíam a causalidade da mudança da regras às chamadas florestas ou reservas, isto é, Unidades de Conservação (UC). Cinco UCs se sobrepuseram à Reserva Garimpeira do Tapajós, que havia sido instituída com quase 3 milhões de hectares em 1983, pelo Ministério de Minas e Energia (MME) (ver Mapa 1). Direcionada, em princípio, aos trabalhadores do garimpo, seu objetivo era evitar conflitos entre garimpeiros e mineradoras (Tedesco 2015). Essa reserva passou a ser cada vez mais acessada pela estrada Transgarimpeira, construída entre 1984 e 1986, em Moraes de Almeida (Itaituba), distrito próximo a Novo Progresso. Desse modo, essas medidas do governo militar haviam fomentado ainda mais o primeiro ciclo do ouro, que movimentou milhares de garimpeiros artesanais para o Tapajós.

Porém, a Constituição Federal de 1988 criou as Permissões de Lavra Garimpeira (PLGs), as quais foram emitidas pelo Departamentos Nacional de Produção Mineral (DNPM) - substituído em 2017 pela Agência Nacional de Mineração (ANM) - para especuladores capitalizados burlarem o licenciamento ambiental. Com isso e os crescentes gastos da mineração industrial, a classe garimpeira passou a contar com cada vez mais empresários, cooperativas e agentes capitalizados do que garimpeiros tradicionais, a quem a Reserva Garimpeira se destinava (Coelho, Wanderley, e Costa 2017; MPF 2020).

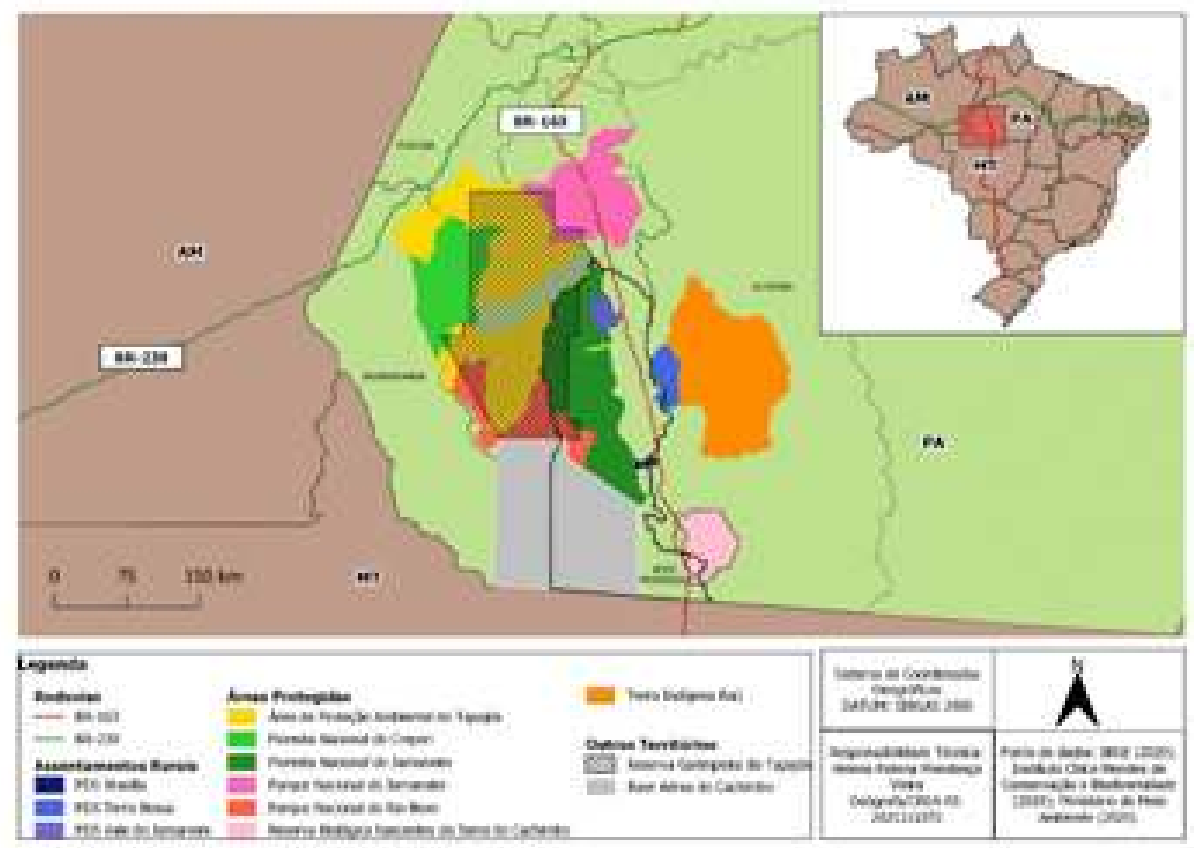

MAPA 1 - Áreas protegidas instituídas durante o governo Lula se sobrepuseram à Reserva Garimpeira do Tapajós, criada pelo governo militar em 1983. A Base Aérea do Cachimbo foi criada pelo governo de Getúlio Vargas, nos anos 1950.

Fonte: Concepção própria. Responsabilidade técnica de Helena Vieira. 
Ainda assim, para representantes da classe garimpeira, a sobreposição das novas reservas acabou com sua proteção frente às grandes empresas, pois multiplicaram os requerimentos de autorização de pesquisa para ANM, impedindo os pequenos garimpeiros de trabalharem legalmente nessas áreas requeridas ${ }^{16}$. Outra queixa era a proibição de mineração em Parques Nacionais ${ }^{17}$. A mineração em Florestas Nacionais (Flonas), por sua vez, vinha sendo alvo de controvérsias jurídicas entre o ICMBio e a ANM, em especial naquelas cujo decreto de criação permitia a atividade ${ }^{18}$ (ICMBio 2010).

Esse foi o caso da Flona do Jamanxim, criada em 2006 com 1.301 .120 hectares (34\% da área de Novo Progresso) sobre a Reserva Garimpeira e reivindicações de posse anteriores. Está inserida no Distrito Florestal Sustentável (DFS) da BR-163, mas não teve concessões florestais devido a ações coletivas por lideranças locais, sobretudo dos produtores rurais ${ }^{19}$. De modo geral, para pequenos a grandes produtores rurais, assim como para as classes dos garimpeiros, madeireiros e empresários, as florestas invadiram áreas produtivas. Naturalizavam a pecuária, mineração e exploração florestal como vocações da região, ao passo em que a floresta era retratada como invasão do governo.

\section{Criminosos atingidos}

Especialmente com a Flona, pequenos a grandes produtores rurais passaram a se apresentar publicamente como colonos que sofreram para ocupar a Amazônia desde os anos 1970 e posseiros que tiveram suas posses reconhecidas pelo Incra antes da mudança das regras. Com base nisso e na legislação que versa sobre requisitos para a criação de UCs, os autointitulados colonos e suas lideranças demandaram o cancelamento, redução e/ou recategorização da Flona para uma categoria mais branda de UC, que permitisse produzir gado, grãos, madeira e minérios.

Reforçavam que apesar de favoráveis à preservação ambiental, precisavam voltar ou continuar a trabalhar e produzir - isto é, desmatar, mexer com garimpo, manejo florestal, pecuária e agricultura. Assim, muitos incorporaram o discurso ambiental, mas enfatizando a culpa do governo de não apresentar alternativas realistas e não os ensinar a fazer diferente, tratando-os de forma homogênea como criminosos ambientais ou bandidos. Repetiam que respeitavam a preservação ambiental, mas não se significasse deixar de trabalhar e produzir. E que os colonos não desrespeitaram o governo porque chegaram antes da criação da reserva e solicitaram documento de posse ao Incra. Quem desrespeitaria os direitos seria o governo.

Essa narrativa dos colonos passou a ser cada vez mais emitida para repórteres, pesquisadores e servidores públicos federais por pessoas variadas que se apresentavam como povo de Novo Progresso e da BR-163. Contudo, não falavam que a maioria daqueles que permaneceram nessa área chegou depois dos anos 1990, sobretudo 2000, com a expectativa de pavimentação da BR-163 (Silva 2011). Nem falavam sobre a concentração fundiária no interior da Flona (ICMBio 2009). Como me disse uma liderança de pequenos agricultores, que passou a ser chamada de traidora quando questionou ações coletivas do povo, "os grandes contam a história como se fossem trabalhador rural” (conversa em maio de 2017).
16 Na época, a Flona do Jamanxim já era alvo de requerimentos das mineradoras: CIA. Vale do Rio Doce, CIA. de Pesquisa de Recursos Minerais (MME), Serabi Mineração Ltda., Tracomal Mineração S.A., Empresa de Mineração Galesa Ltda. (Ricardo e Rolla, 2006). Em 2011, a Anglo American requereu ao então DNPM um perímetro que abrange mais da metade da Flona do Jamanxim (Barros, 2012).

17 Em Recomendação de março de 2020 à ANM, o MPF indicou a revisão dos limites da Reserva Garimpeira consoante as categorias de UCs sobrepostas.

18 O Parecer $n^{\circ} 21 / 2014$ da Advocacia-Geral da União (AGU) impossibilitou a mineração nas UCs criadas pelo Plano BR-163 Sustentável.

19 Principalmente o boicote ao Conselho Consultivo da Flona do Jamanxim. Ver: Correa, Castro e Nascimento (2013), Lacerda (2015) e Silva (2011). 
Por vezes, o povo da região se retratou ainda como atingidos pela criação das reservas (ver Imagens 1 a 3). Essa foi uma das formas de buscarem o reconhecimento de suas pautas, apropriando-se de uma categoria empregada no Brasil desde os anos 1980 por comissões de contestação a hidrelétricas que deram origem ao Movimento dos Atingidos por Barragens (MAB). De modo análogo a esses atingidos, o povo da BR-163 denunciava a subordinação do fator "sociocultural" aos fatores "técnicos" do Plano BR-163 Sustentável - elaborados, segundo eles, por pessoas que não conhecem a realidade da região - e o descumprimento de procedimentos técnicos exigidos por lei (Weitzman 2022).

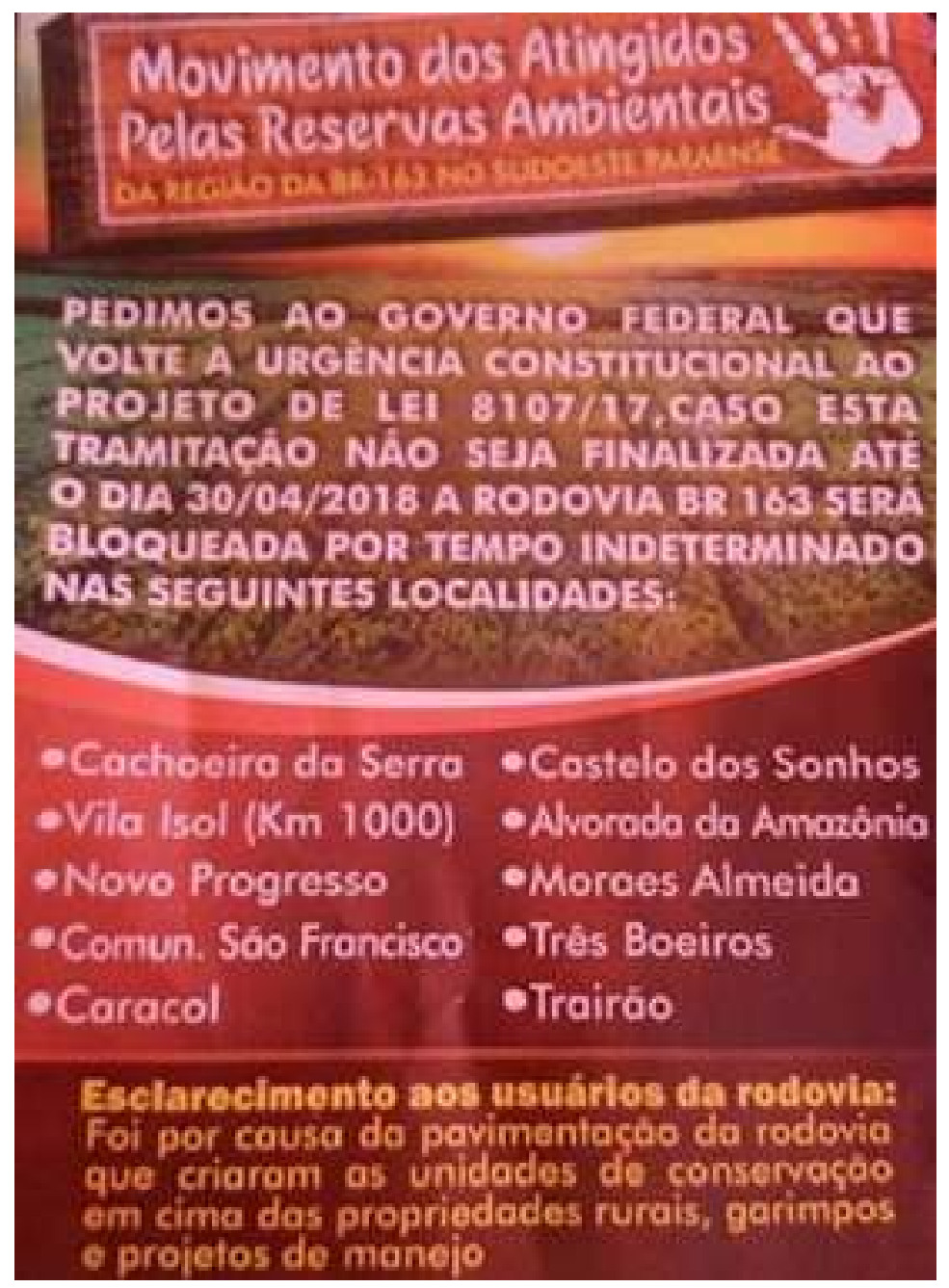

Logo, embora tenham reformulado práticas, sentidos e linguagens referidos ao meio ambiente (Leite Lopes 2006), agentes mais capitalizados deram continuidade à devastação ambiental (Almeida, Neto e Martins 2005). E o fizeram ao abstrair a justificativa de pequenos produtores, agricultores familiares, garimpeiros e trabalhadores rurais para todo o povo: precisavam continuar trabalhando e produzindo para sobreviver. Ao mesmo tempo, reafirmavam que os trabalhos e produções relevantes seriam os vinculados às vocações econômicas, e não o extrativismo de pequeno porte, a garimpagem artesanal ou a agricultura familiar.
IMAGEM 1 - O Projeto de Lei $8.107 / 2017$ deu continuidade a demandas de manifestantes de bloqueios da BR-163 para alterar a Medida Provisória (MP) $n^{\circ} 756 / 2016$, assinada por Michel Temer, que flexibilizava a Flona do Jamanxim (Torres e Branford, 2017). Temer havia vetado alterações à MP e negociou o PL 8.107.

Fonte: Material recebido em trabalho de campo, em maio de 2017. 


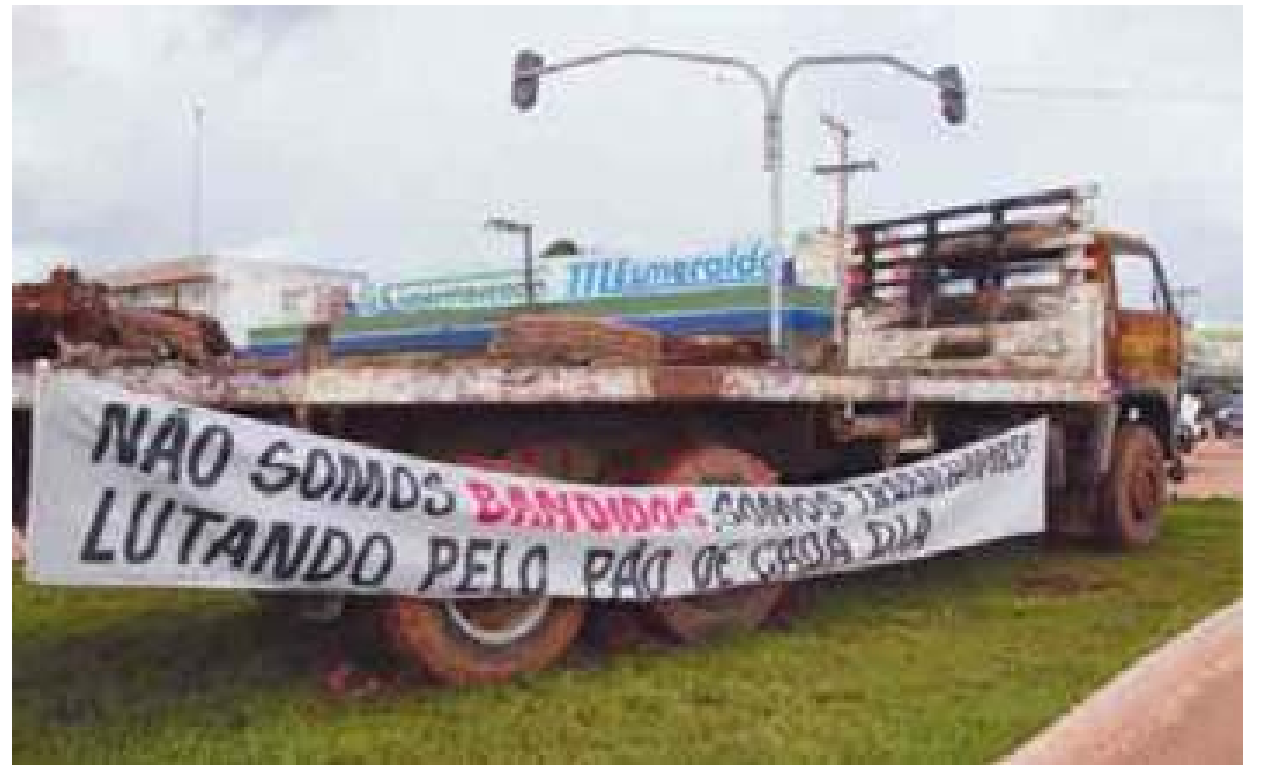

\section{Colonização sustentável: crise da madeira e do desemprego}

Apesar do discurso da crise ter sido articulado e reproduzido sobretudo por empresários da madeira e do ouro e grandes produtores rurais, aqueles com menos condições eram reconhecidos por terem maiores dificuldades de adaptação aos novos tempos. Assim, não só pequenos produtores rurais, mas pequenos garimpeiros, trabalhadores das serrarias e do setor de serviços foram pegos de surpresa com o súbito desemprego e restrições ambientais. Foram esses trabalhadores e trabalhadoras que engrossaram as listas de candidatos à política de reforma agrária. Muitos ingressaram nos acampamentos que vinham sendo organizados desde 2003 na beira da BR-163 pelos sindicatos de trabalhadores rurais de Altamira e Novo Progresso, de modo a demandar ao Incra a criação de projetos de assentamentos de modalidade convencional (PA).

Em ofícios enviados em 2005 a autoridades estatais, esses sindicalistas de trabalhadores rurais denunciavam a grilagem e os assassinatos por latifundiários e exclamavam a necessidade de terra para trabalhar em PAs. Mencionavam a crise socioeconômica pelo viés do desemprego e da fome que ele gerou. Já os ofícios de vereadores e secretários municipais demandavam assentamentos associando-os com a demanda de resolução da crise da madeira, atividade responsável nos anos anteriores pela febre de empregos (Incra 2005) (ver Fotografia 1).
FOTOGRAFIA 1 - Caminhão de carregamento de madeira, queimado em ação e fiscalização do Ibama. Segundo notícias de veículos locais, o responsável pelo ato, de 59 anos, foi o dono do caminhão e moto queimados pelo Ibama. Durante o evento, ele usou um colete dizendo: "O Ibama destruiu minha ferramenta de trabalho. Hoje fui eu, amanhã pode ser você!". O ato reuniu cerca de mil apoiadores locais.

Fonte: Correa, Castro, e Nascimento $(2013,125)$. 

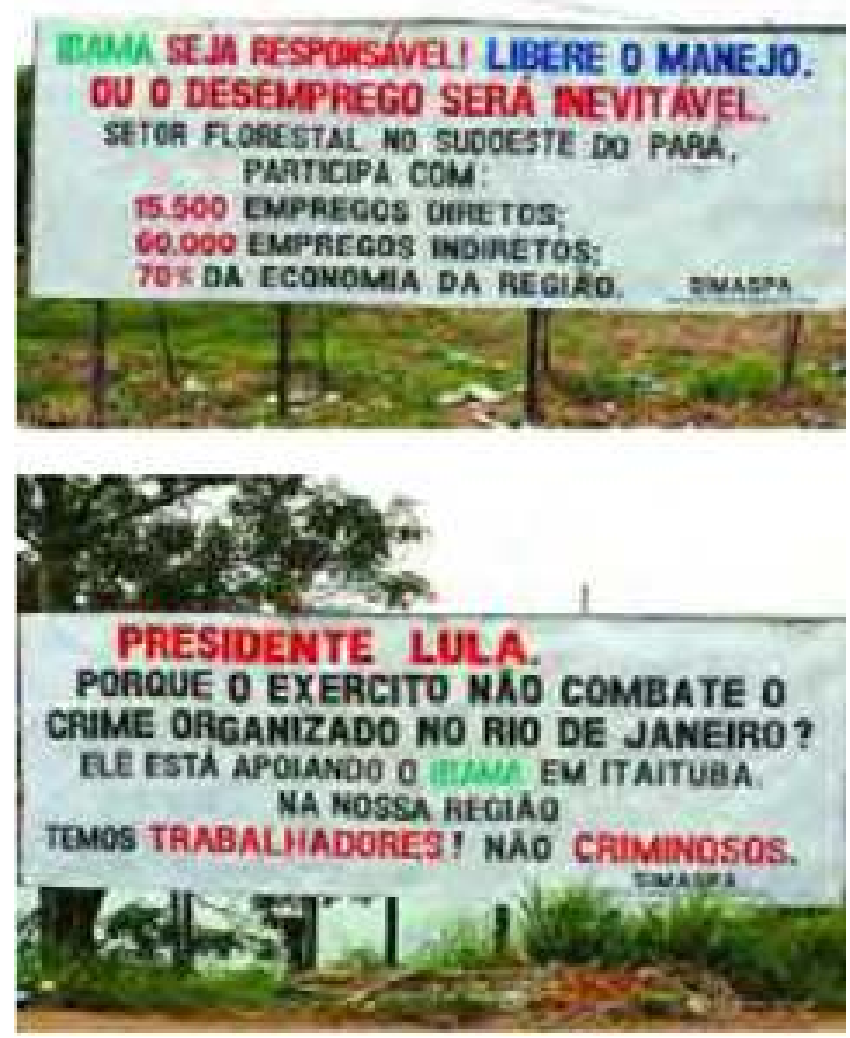

Assim, o aumento de desemprego confluiu com as negociações de políticos locais e madeireiras com os diretores e superintendentes do Ibama e Incra para terem acesso a planos de manejo em conformidade com a Portaria de 2004. Como Torres (2012) demonstrou, em 2005 e 2006 o Incra do Oeste do Pará criou dezenas de assentamentos da modalidade Projeto de Desenvolvimento Sustentável (PDS). Ao contrário do PA, que prevê a destinação individual de titulações e reservas legais, o PDS estabelece a destinação coletiva a assentamentos em áreas de floresta primária, pois sua intenção era favorecer populações extrativistas tradicionais. O PDS foi percebido não só como acesso à terra pelas famílias acampadas que demandavam reforma agrária, mas como meio de obtenção de licenciamento de planos de manejo florestal pelos madeireiros. A ilegalidade desse conluio levou à suspensão desses assentamentos por anos, através de Ação Civil Pública movida pelo Ministério Público Federal (MPF) contra o Incra e o estado do Pará.

Um desses "assentamentos de papel", como ficaram conhecidos, é o PDS Terra Nossa, instituído em 2006 com quase 150 mil hectares ${ }^{20}$ (ver Mapa 1). Devido à Ação Civil Pública, o Terra Nossa foi liberado judicialmente somente em 2011, não recebendo documentação, crédito, infraestrutura e assistência técnica. Por isso, esses assentados criticavam o governo não pela crise, mas pelo Incra ter-lhes abandonado sem seus direitos, o que causou muito sofrimento e dificuldades para trabalhar na terra. Pior, tiveram que lidar com humilhações de produtores rurais, donos de garimpos, mineradoras e madeireiras que aproveitaram o abandono para disputarem essa área por meio de embates e articulações com agentes governamentais. Em 2015, esses agentes quase conseguiram reduzir 80\% da área do PDS mediante outro conluio ilegal com o Incra. Tiveram apoio de associações de assentados do Terra Nossa, que passaram a preferir realizar acordos para conseguirem
FOTOGRAFIA 2 - Dois outdoors assinados pelo Simaspa, Sindicato das Indústrias Madeireiras do Sudoeste do Pará, fotografados em setembro de 2004.

Fonte: Maurício Torres (2005, 315).

20 90\% da área do PDS Terra Nossa se situa no município de Altamira, mas seu acesso se dá pela BR-163, em Novo Progresso. 
ter acesso à terra, após quase uma década de luta sem obterem direitos e depois de uma derrota judicial favorável a produtores rurais (Lacerda 2015). Porém, o MPF impediu a redução (Torres, Doblas e Alarcon 2017).

Assim, para essas famílias assentadas, o abandono do governo se concretizava em sentido semelhante ao denunciado pelos pioneiros de Novo Progresso quanto à colonização nos anos 1980. Afinal, reproduziu situações de precariedade e de vivência de humilhações por agentes que desejavam expulsá-los do PDS por meio de contestações jurídicas e administrativas e/ou armas - experiência humilhante não raro vivida em outros locais onde viveram anteriormente. Ademais, muitos assentados também se chamavam de colonos. E alguns se valorizavam por serem pioneiros no assentamento como forma de legitimação de sua luta pela regularização do PDS. Embora alguns falassem sobre disputas com determinados produtores rurais, mineradoras e madeireiros, apontavam o governo - em particular, o Incra e parte de seus servidores -, como culpado por seus problemas (Lacerda 2022).

Por fim, como Beatriz Heredia (1983) indicou quanto à cana de açúcar no Nordeste, versões sobre crises de vocações econômicas costumam ser mais disseminadas por quem vê ameaçadas suas relações e posições sociais. No caso dos assentados, a criação do PDS Terra Nossa foi mais um evento de abandono, humilhações e sofrimentos em uma trajetória de sucessivas expropriações e busca de melhorias de vida. A imagem de crise, vinculada ao desemprego e à fome, predominava entre seus representantes, ao interagirem com autoridades e demais agentes ao organizarem ações de contestação.

\section{De heróis a vilões: crise moral e existencial}

Como vimos, para habitantes nada ou muito capitalizados, o Plano BR-163 Sustentável foi lido como uma ameaça para as formas de vida que os atraíram para a região e, especialmente no caso dos colonos, para seu sentido de história. Um sentimento que perpassa diferentes segmentos da população da BR-163, não só no Pará como no Mato Grosso, é o da traição do governo. Com isso, denunciavam que depositaram sua confiança em regras governamentais que lhes deram direitos, mas o governo mudou as regras, gerando ansiedade frente a um futuro incerto.

Conforme um produtor disse para a jornalista Carolina Glycerio (2008), “a gente se sente traído porque a gente investiu em uma área que não tinha nada, e agora eles estão tirando um direito que nós adquirimos". Como sintetizou Seluchinesk (2008) ao analisar as narrativas de colonos de cidades mato-grossenses da BR-163, de heróis da história de colonização, se tornaram vilões - não só para o governo, mas para a nação, sendo retratados em reportagens jornalísticas por termos como piratas, desmatadores, grileiros e criminosos. Isso teria levado a uma "crise identitária” (Ibid. 229), que poderíamos interpretar como moral e existencial. O deputado federal ruralista Zequinha Marinho (PSC/PA), que manteve relações de proximidade com lideranças da luta da Flona do Jamanxim, também retratou essa crise: 
[...] naquele tempo [Ditadura Militar], o homem era companheiro do Governo, companheiro da nossa Nação, para desbravar a Amazônia. [...] muitos tombaram com doenças diversas da Amazônia. Agora, aquele camarada que era um herói virou um vilão. Hoje, o homem da Amazônia é considerado uma pessoa que anda na contramão [...] O povo da BR-163, especificamente do Município de Novo Progresso, vive a maior angústia da sua vida. [...] Tem até gente se suicidando. Essas pessoas estão perdendo tudo de uma hora para outra. [...] [...] (09/10/2009, discurso proferido na Câmara dos Deputados, grifos meus).

Nesse sentido, costumam repetir que o governo federal lhes abandonou desde os anos 1980, voltando décadas depois somente para reprimi-los. E que o pessoal do meio ambiente queria esvaziar a Amazônia. Isso era corroborado pelos mapas de zoneamento do Plano BR-163 Sustentável apresentados por técnicos nas consultas públicas, os quais não mostravam a ocupação humana existente, mas áreas completamente novas, com um novo vocabulário e uma nova história. Segundo Campbell (2012), a população de Castelo dos Sonhos (distrito vizinho a Novo Progresso) criticou em uníssono o zoneamento do Plano BR-16321, pois esse sugeria que o modelo de desenvolvimento anterior havia fracassado, o que os implicava indiretamente não só como vilões, mas como culpados pela precariedade em que viveram até então ${ }^{22}$.

Como um médio produtor definiu, o meio ambiente passou a mandar no governo federal, "eles pegaram um direito tão grande que hoje o governo é do meio ambiente”, pois “a lei deu muito poder pra eles" (Sandro, conversa em novembro de 2013). Um dos seus exemplos foi o Decreto $n^{\circ} 6.514 / 2008$, que prevê a destruição de equipamentos usados para atividades ilegais, com destaque para a mineração e extração madeireira, pelo Ibama.

Em entrevistas e documentos das consultas públicas, o governo federal era denunciado, por um lado, pela ausência de direitos e do Incra. E por outro lado, pelo autoritarismo representado pelo Ibama e MMA. Isso era ilustrado pelo contraste entre o fechamento da unidade local do Incra por falta de recursos e a abertura da sede do Ibama em Novo Progresso. Essa presença do Ibama era descrita como terrorismo e humilhação, associados aos helicópteros que cruzavam o céu nas caras operações em que multavam áreas, apreendiam gado e queimavam equipamentos, bem como à circulação de servidores armados ou acompanhados da Força Nacional pela cidade.

Portanto, a crise significou ainda um choque moral (Jasper 2018) com relação ao governo, o que possibilitou a construção de lealdade entre grupos e classes antes mais abertamente diferenciados e antagônicos, como os colonos e os garimpeiros - os quais não eram bem-vistos pelos primeiros, segundo as pioneiras sulistas Oravec (2008) e Schneider e Fortes (2011). Assim, formas anteriores de narrar a história e as oposições sociais existentes na colonização foram relidas à luz do abandono e repressão que teria tornado todos vilões.

A construção da categoria de governo, por seu turno, facilitava a abstração de
21 O Zoneamento Ecológico-Econômico da BR-163 se contrapôs ao Macrozoneamento Ecológico-Econômico do Estado do Pará, o qual reconhecia a Reserva Garimpeira do Tapajós e projetava a expansão e consolidação de áreas consideradas produtivas no entorno da BR-163. Porém, o zoneamento federal prevaleceu.

22 Para uma situação em que uma população é culpada pela precariedade em que vive, o que integra políticas de rebaixamento do Estado, vivenciadas como humilhação, ver Gonçales (2021). 
um inimigo comum contemporâneo, embora se referissem a políticas públicas de diferentes governos. Por exemplo, apontavam que o governo era contraditório, pois o Incra exigiria desmatamento para reconhecer a posse de terra e o Ibama puniria o desmate. Desse modo, produziam contemporaneidades entre eventos não contemporâneos (Das 1995); afinal, foi uma Portaria do Incra que demarcou as novas regras que, a princípio, passavam a não mais reconhecer o desmate como prova de ocupação. Por outro lado, por vezes as novas regras contradiziam políticas anteriores, como a Reserva Garimpeira, causando indefinições jurídicas acerca do uso de cada território.

Através do enquadramento da crise, o povo da região confrontou os projetos de desenvolvimento da ditadura militar e da sustentabilidade alicerçada no crescimento econômico, observando contradições internas e promessas não cumpridas de cada modelo de integração e desenvolvimento. Ademais, alguns agentes notaram atualizações do modelo de colonização anterior no novo modelo sustentável, como os assentados que se viam como colonos e pioneiros abandonados. Ou o colono que disse a Campbell (2012) que seriam os novos índios, pois seriam expulsos pela pavimentação da rodovia nos marcos da ambientalização, ao passo em que os indios haviam sido expulsos por colonos como ele. Dessa forma, instauraram conflitos socioambientais direcionados à crítica da gestão da região por sucessivos governos federais, por vezes englobados como um único governo injusto, que reproduz precariedades, sofrimentos e humilhações.

\section{A revolta que para a riqueza que passa}

Os bloqueios de rodovia se tornaram a ação coletiva de enfrentamento mais empregada desde o governo do ex-presidente Lula, que representa a mudança das regras que instaurou a grande crise na região. Se as ações coletivas em geral conquistaram legitimidade perante o povo da BR-163 por causa da crise que o governo criou, no caso dos bloqueios de rodovia essa justificação era ainda mais importante, haja vista ser uma forma de ação controversa pelo seu caráter de enfrentamento, que pode ser interpretado como drástico ou violento (Das 1995). Por um lado, prejudicaria a circulação de moradores e de mercadorias, já dificultada pelas condições precárias da BR-163. Ao mesmo tempo, os bloqueios costumavam ser noticiados como fruto de raiva e descontrole, o que poderia piorar sua imagem externa de vilões. Por isso, cabia às lideranças tentar controlar os manifestantes para evitar uma imagem negativa para a imprensa (Lacerda 2019). 


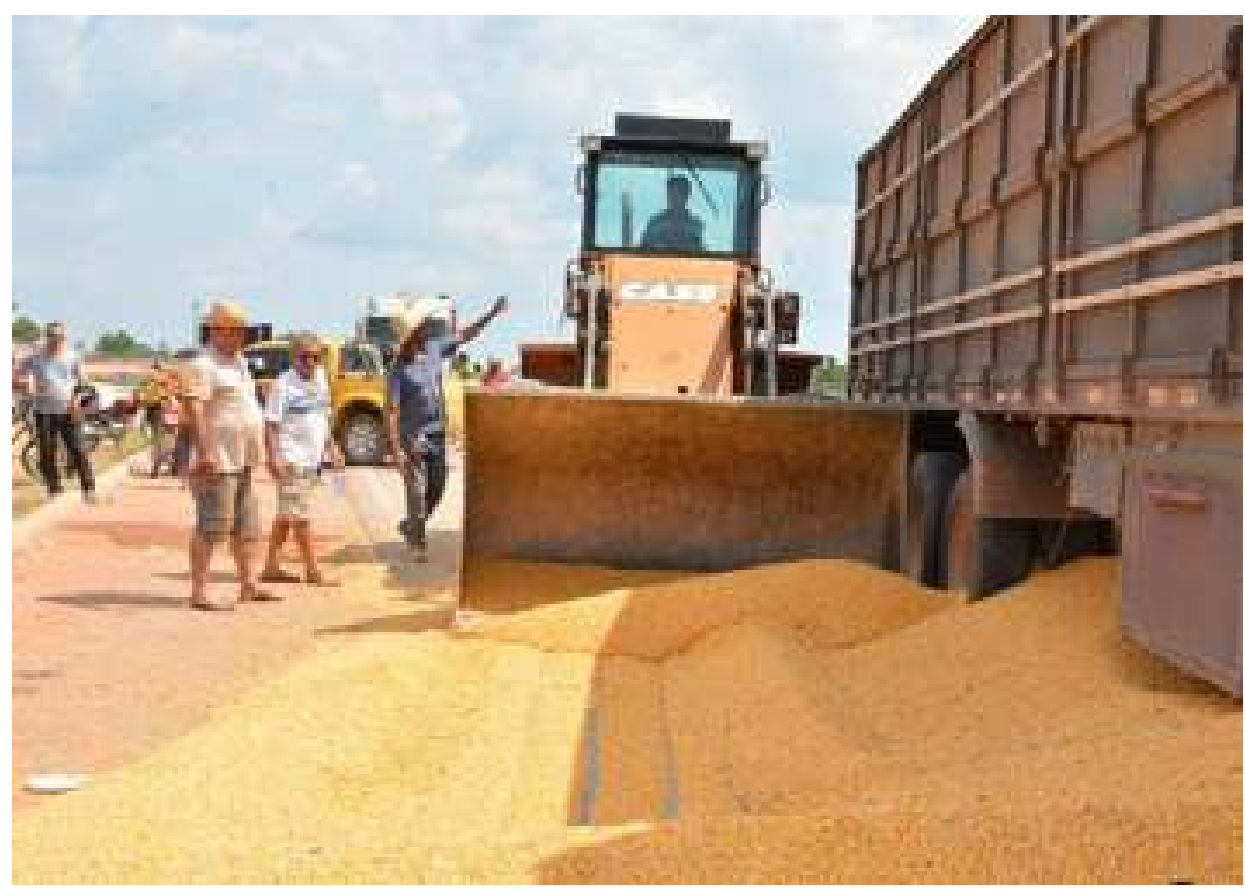

Mesmo no seu cotidiano, ações movidas pela raiva eram controversas, objeto de debate em termos de sua legitimidade, por serem imprevisíveis e poderem ferir pessoas justas - como observou Oravec (2008, 43-5). No caso das ações coletivas, a revolta remetia à mobilização da raiva em torno da indignação coletiva contra adversários, a quem buscavam incutir medo (Jasper, 2018). Por isso, nas reportagens, era recorrente a imagem de que o "clima está tenso" e ameaças de que a "situação poderá fugir do controle" caso as autoridades não dessem alguma resposta ao bloqueio.

Por outro lado, era igualmente reconhecida sua eficácia em termos de reconhecimento relativo das pautas pelo governo federal, o qual respondia ao bloqueio com ofícios com novas promessas e/ou reuniões com os órgãos competentes em cada assunto. Sabiam que essa eficácia era decorrente da BR-163 ser uma rota de escoamento de grãos do agronegócio mato-grossense, sendo declaradamente bloqueada para pressionar, chamar a atenção e forçar o governo a firmar acordos - por isso, a ameaça de bloquear a BR-163 se tornou uma ação coletiva baseada em bloqueios já realizados (Lacerda 2019).

Não raro, comparavam os incentivos do governo ao agronegócio no Mato Groso com as restrições ambientais impostas no Pará. Explicavam que, com o anúncio da pavimentação da BR, a paralisação da circulação de caminhões de exportação se tornou a única ferramenta para suas demandas andarem. Reclamavam que o governo passou a vê-los não como produtores equivalentes aos mato-grossenses - expectativa nutrida por Zé Coruja (2004) ao escrever antes da crise -, mas como corredor de exportação; isto é, como passagem e não produção de riqueza do agronegócio (ver Imagem 2).
FOTOGRAFIA 3 - "Caminhoneiro tentou furar bloqueio e foi impedido por manifestantes. Parte da carga foi jogada na pista da rodovia”. Esse bloqueio de 2013 reuniu pautas do PDS Terra Nossa, da Flona do Jamanxim e da fiscalização ambiental em seu interior. Assentados contaram que queriam ter queimado o caminhão, mas foram controlados por sindicalistas (Lacerda, 2019).

Fonte: G1 (Manifestantes..., 2013). Foto: Gilvanne Cardoso. 


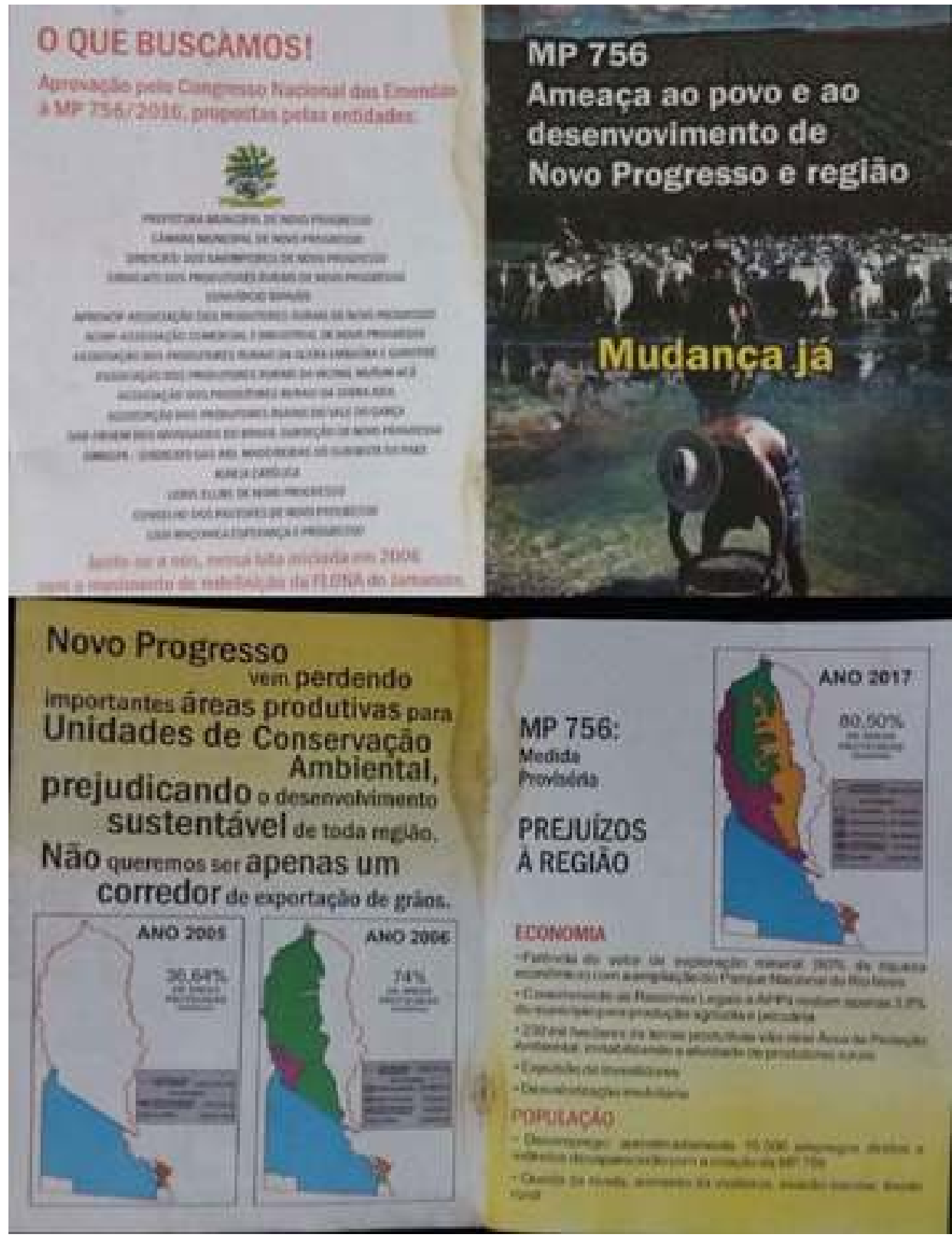

Para as lideranças das classes e grupos mobilizados nos bloqueios, esses permitiam que suas lutas fossem noticiadas pela imprensa e, ao mesmo tempo, prejudicariam financeiramente os grandes produtores rurais do Mato Grosso articulados com o governo federal ${ }^{23}$. Desse modo, pretendiam sensibilizar públicos mais amplos e interferir no campo político (Champagne 1984), ao denunciarem o governo como responsável pelos seus sofrimentos, ansiedades e humilhações. Tentavam justificar assim suas indignações e revoltas frente à precariedade da região e ao desrespeito de direitos morais e legais ${ }^{24}$. Enquanto conversávamos sobre o bloqueio da BR-163 de 2013, um ex-produtor da Flona explicou a revolta que motiva essa forma de ação tanto pela espera da resolução do problema pelo governo, quanto pelos abusos e humilhações da fiscalização ambiental pelo Ibama:

[...] eu respeitei a lei, tô esperando, não cometi infração [...] Como o governo vem prometendo [e] nunca legalizou [...]. Tô esperando um ano, esperou dois, é oito, todo mundo, 90\% revoltado, tranca a BR. O Ibama [...] diz que
IMAGEM 2 - Panfletos dos movimentos da medida provisória de 2017.

Fonte: trabalho de campo em Novo Progresso em 2017.

23 Como o sojicultor mato-grossense e ex-ministro da Agricultura Blairo Maggi (2016-2018).

24 Para análises de mobilizações sociais em torno de uma ou mais dessas emoções, ver: Boltanski (2004), Comerford (1999), Das (1995), Gonçales (2021), Jasper (2018), e Lacerda (2014). 
tem autoridade pra isso, queima caminhão [...], barraco de peão. [...] Ao invés de amenizar a situação vai cada vez agravando mais. [...] Aqui o povo aqui é pacífico [...] tá esperando pelo governo, tá com paciência, às vezes se revolta, fala uma coisa ou outra, mas taí esperando [...]. (médio produtor que participou do bloqueio de 2013, novembro de 2013).

Nessa fala, chama atenção o trabalho do tempo na produção da revolta conjunta. São anos de humilhações e desrespeitos aos direitos de toda uma população, desde o peão aos donos de caminhões queimados. A isso, contrapõem-se os valores do povo progressense: paciente e pacífico.

\section{Índios e brancos: invasões inversas}

Ao passo em que tentava justificar ações de revolta devido a injustiças, o povo da BR-163 também podia se mostrar revoltado com essa forma de protesto. Sobretudo se fosse protagonizada por indígenas, como ocorreu em 2011, quando um blog local publicou uma série de notícias, entre elas a intitulada: "População está revoltada com as atitudes dos índios Kayapó” (Ribeiro 2011a). Cerca de cem indígenas interditaram a rodovia para demandar serviços públicos nas aldeias. Além disso, paralisaram o trabalho das empreiteiras que asfaltavam a BR-163. Nos comentários à notícia, havia duas posições opostas: os índios deveriam trabalhar para não atrasar o desenvolvimento; os brancos deveriam copiar os indios na luta por seus direitos, em especial frente a políticos que não cumprem suas promessas. Em seguida, o blog noticiou que "o governo atendeu os indígenas" em menos de 48 horas (Ribeiro 2011b).

Esse imaginário vai ao encontro do estereótipo de "índios bravos": negativo, por obstruir a colonização e o desenvolvimento; positivo, pela eficácia da sua desobediência perante a autoridade nacional (Pacheco de Oliveira 2016). Não raro, ressentiam que isso ocorria porque o governo se importaria mais com os indios do que com os colonos brancos. De todo modo, muitos progressenses valorizavam a habilidade dos Kayapó em protestos, o que os levava a chamá-los para apoiar os bloqueios de rodovia. Assim, produtores da Flona me contaram com orgulho que em 2017, quando bloquearam a BR-163 demandando a flexibilização da UC, tiveram ajuda de indígenas Kayapó de quem se tornaram amigos. Com isso, buscavam afirmar a legitimidade e a força da luta da Flona. Todavia, ao falarem da luta da Flona do Jamanxim, suas lideranças rememoravam sua participação nas ações coletivas de 2003, que resultaram na redução da Terra Indígena (TI) Baú dos Kayapó. Para eles, foi a primeira vitória contra invasões do governo às suas áreas produtivas (Torres, Doblas e Alarcon 2017, Lacerda 2015).

Em 2003, o sindicato dos produtores rurais (Siprunp), empresas madeireiras, duas mineradoras e a prefeitura de Novo Progresso bloquearam por mais de dez dias a BR-163, após tentativa frustrada de negociação em Brasília. A pauta era contra a demarcação da TI Baú na área entre o rio Curuá e a divisa de Novo Progresso com o município de Altamira. Embora tivesse sido criada pelo Ministério da 
Justiça (MJ) em 1991, com 1,85 milhões de hectares, foi no governo Lula que o MJ iria finalizar a demarcação e indenizar os milhares de ocupantes da área indígena.

A imprensa nacional e estadual destacou o teor violento da manifestação. Anunciavam a possibilidade de confronto armado, enquanto algumas lideranças locais falavam que os Kayapó eram amigos da população e que o problema havia sido causado pela Funai. Em paralelo, uma comissão de políticos, empresários e produtores locais negociou um acordo com representantes dos Kayapó na sede da Funai em Colíder (MT). O bloqueio acabou quando a Justiça Federal suspendeu a demarcação da TI Baú. O acordo foi ratificado pela Portaria n $n^{\circ}$ 1.487/2003 do MJ, que reduziu 317 mil hectares da TI, na área onde hoje se situa o PDS Terra Nossa.

Lideranças engajadas na flexibilização do PDS Terra Nossa, por sua vez, organizaram um bloqueio na BR-163 em 2016 com os Kayapó. Além de pautas diferentes respectivas a cada território - unidade local da Funai e casas de saúde e cultura indígena; regularização do PDS acordada com autodenominados posseiros do entorno -, ambos os grupos demandaram serviços públicos (como vicinais e energia) com o "objetivo chamar atenção do governo federal para cumprir com as promessas por conta da construção da rodovia BR 163 na região" (Piran 2016).

Porém, o bloqueio foi separado em dois pontos, pois segundo uma liderança indígena: "índio não se mistura com branco". O repórter explicou que "na região os índios têm suas queixas dos 'brancos', acusados de invadir e degradar suas terras e matas" (Abandonados 2016). Logo, a categoria de invasão era empregada reciprocamente. Contudo, o acordo de 2003 permitiu relações com indígenas anunciadas como de amizade e apoio, inclusive em manifestações conjuntas. De todo modo, os Kayapó, cujo território havia sido cortado pela BR-163 na ditadura militar, continuaram enfrentando invasões cotidianas às suas terras indígenas. Como os assentados, sua luta não apresentava uma versão da crise das vocações, embora compusessem ações coletivas com o povo revoltado com a ambientalização.

\section{De vilões a heróis: não somos bandidos, queremos trabalhar}

A partir do governo do ex-presidente Michel Temer (2016-2018) e, sobretudo, com Jair Bolsonaro (2019-2022), o tempo da ambientalização parecia enfim ter ficado no passado para o povo da região. Em Novo Progresso, 72,75\% dos eleitores votaram em Bolsonaro no primeiro turno das eleições de 2018; 78,18\% no segundo turno.

Um dos efeitos do governo de Bolsonaro foi a intensificação das invasões de TIs por garimpeiros, madeireiros e produtores rurais. Ao lado disso, as compensações da pavimentação da BR-163 (EIA da BR-163) passaram a atrasar e serem ameaçadas de cortes, o que comprometeu os trabalhos do Instituto Kabu, criado em 2008 por indígenas Kayapó. Consequentemente, apesar de serem minoritárias, algumas lideranças de aldeias se associaram a garimpos e se desligaram do instituto ${ }^{25}$.

Isso se deu no contexto de revalorização da mineração pelo governo federal, o que fortaleceu a pauta da Reserva Garimpeira do Tapajós. Em 2017, ganhou corpo o movimento "Garimpeiro não é bandido, é trabalhador", que resultou em
25 "Garimpo e cisão". Disponível em: https://www.kabu.org. br/garimpo-e-cisao/. Acesso em: 10 dez. 2021. 
bloqueios da BR-163 em 2019 e 2020, que contaram com a presença de indígenas Kayapó e Munduruku (ver fotografia 4):

Os garimpeiros contam com um apoio de peso: o presidente da República Jair Bolsonaro, que já foi garimpeiro e seu pai também realizou o ofício em Serra Pelada [...] "Porém na nossa região o que nos afeta mais é essa questão das áreas de conservação, que foram criadas através de decretos de 1998 a 2006, e sobre o decreto ele [Bolsonaro] não pode fazer nada... Precisa direcionar para que se tenha mudança na lei" (CAMILO 2020).

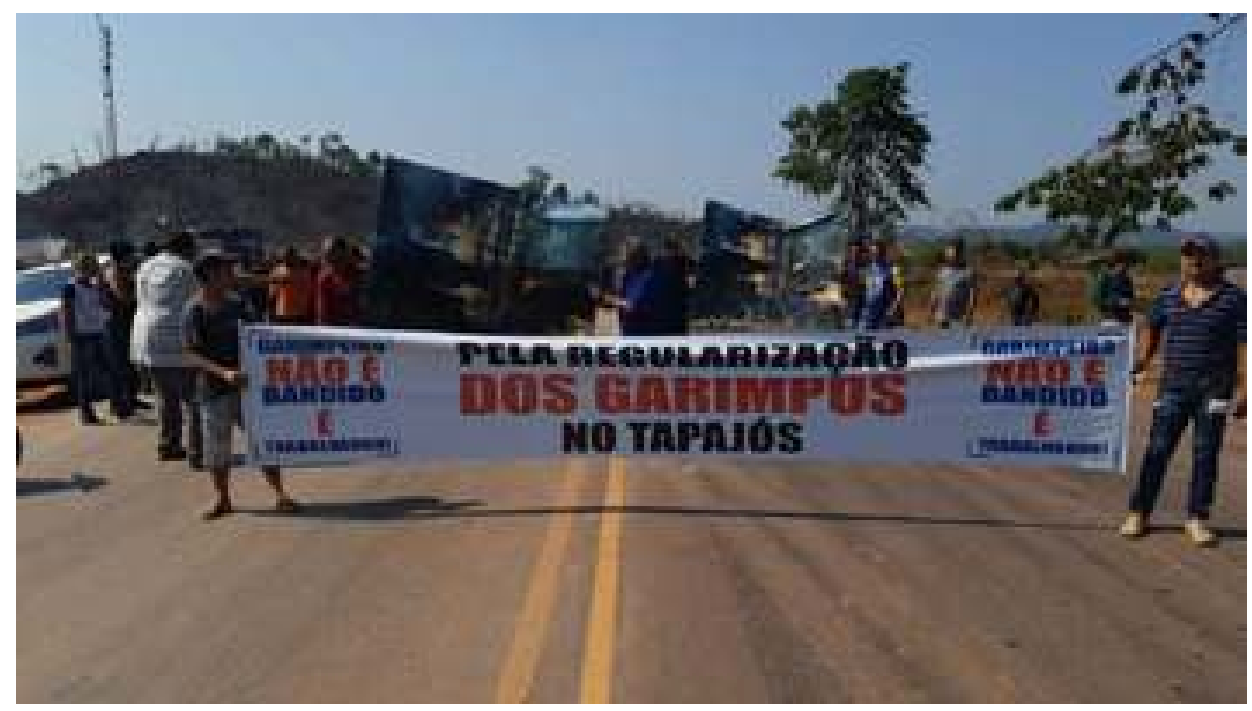

Já os Kayapó vinculados ao Instituto Kabu se manifestaram em cartas públicas contra os garimpos e a exoneração da coordenadora da Funai, órgão que passou a ser visto como inimigo dos indígenas (Valente 2020). Em 2020, bloquearam a BR-163 demandando: retomada de ações do Ibama para expulsar madeireiros e garimpeiros das TIs, paralisadas pelo governo Bolsonaro; melhorias na saúde; renovação do PBA-CI; e consulta pública referente à nova ferrovia (Ferrogrão) desenhada em paralelo à BR-163 (ver fotografia 5).
FOTOGRAFIA 4 - Atrás da faixa, há fotografias impressas de maquinários queimados pelo Ibama.

Fonte: Garimpeiros (2019). 


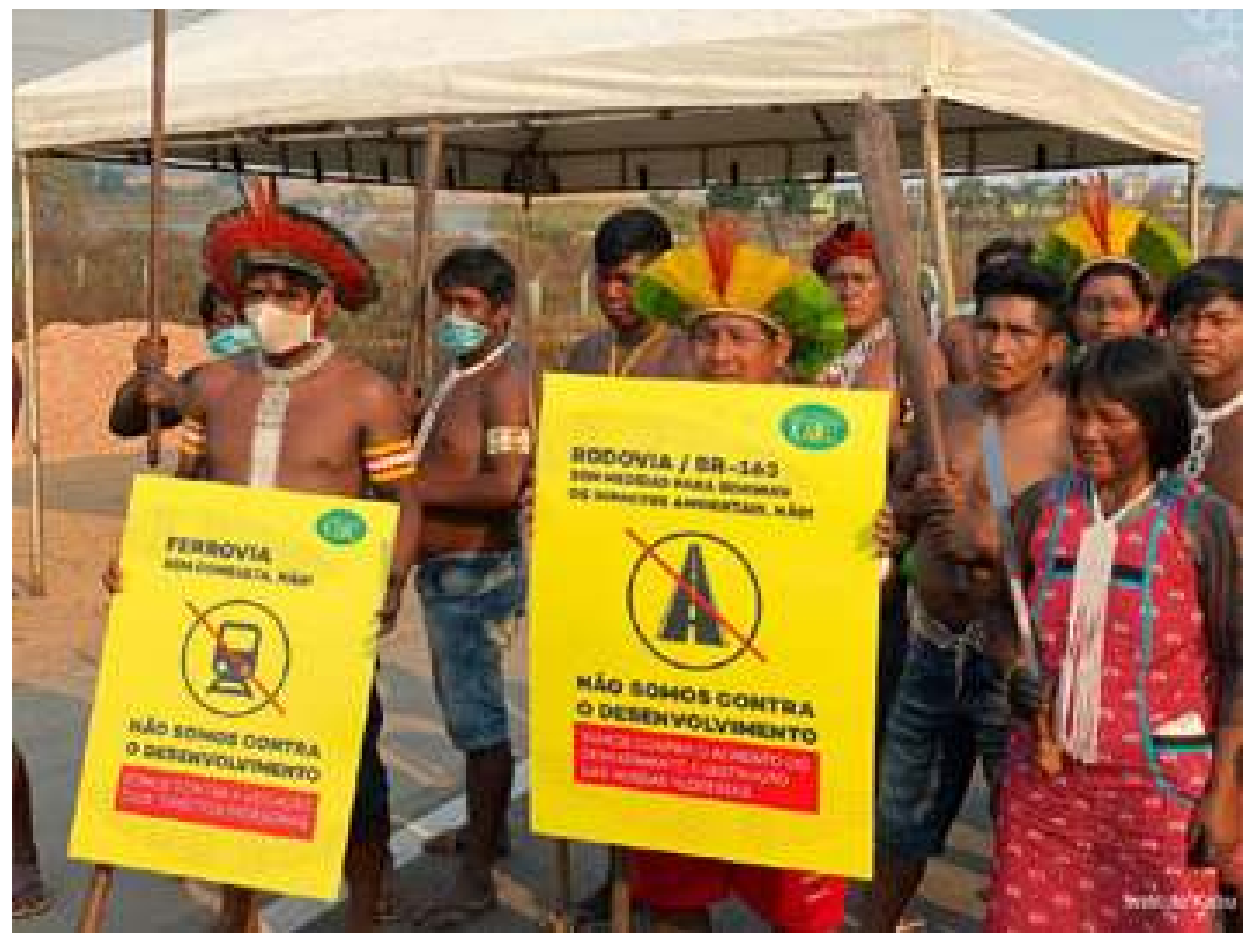

Ao lado disso, com Bolsonaro, lideranças viram possibilidades de flexibilizarem a Flona do Jamanxim por meio não da revolta, mas do diálogo com o governo. Nos primeiros meses de presidência, foram recebidas no Ministério da Agricultura (MAPA) (Barros 2019a). Já o PDS Terra Nossa, mesmo após recomendações do MPF (2020b) para expulsão de grileiros e paralisação da mineração em seu interior, segue sendo palco de assassinatos, queimadas, extração de ouro e exploração de madeira com anuência do Incra (Barros 2019b).

Como Bemerguy (2021) argumentou, a adesão ao bolsonarismo pode ser vista como atualização de "gramáticas e imaginários coloniais" vinculados à incompletude da rodovia BR-163, vivenciada em sua precariedade. A crise da ambientalização possibilitou que o povo da BR-163 se manifestasse conjuntamente contra o discurso de Lula de que seriam "bandidos, grileiros e desmatadores de floresta" (Tarca 2020). Com Bolsonaro, as divergências internas ao povo, às classes e povos indígenas têm sido mais publicizadas. Além disso, a responsabilização pelos problemas se diluiu em outros agentes, como o Legislativo. Mas ainda há oposição ao governo federal, especialmente pelos Kayapó e assentados do Terra Nossa, para quem a crise não tinha centralidade.

\section{Conclusão}

O enquadramento de diferentes problemas e faces das crises (das vocações, do desemprego e moral-existencial) como uma crise causada pela ambientalização do governo mobilizava imagens da população da BR-163 paraense como comunidade moral e afetiva em variados bloqueios de rodovia e discursos públicos. Desse modo, sentimentos nutridos desde a colonização com a abertura da BR-163, como sofrimentos, humilhações, lutas e amor ao lugar em meio ao abandono do governo, se tornaram raiva, indignação e revoltas frente às traições, repressões, invasões e desres-
FOTOGRAFIA 5 - Lideranças Kayapó em bloqueio seguram cartazes do Instituto Kabu reivindicando consulta pública e compensação ambiental.

Fonte: Instituto Kabu. 
peitos aos direitos de trabalhar e produzir.

Nesse processo de comunização, identidades e oposições sociais foram reformuladas. As diferenciações dos colonos perante os garimpeiros, presentes nas memórias de colonização, foram costuradas pelo pertencimento ao povo vilanizado, criminalizado e afetado por políticas do governo. A amizade entre brancos e indios foi reafirmada, apesar das invasões e da sua não mistura. Ainda que com desigualdades e tensões internas, se engajaram juntos em ações coletivas tendo em vista a transformação de um cotidiano compartilhado de precariedades e de promessas não cumpridas, tanto por parte do modelo de desenvolvimento da ditadura militar quanto do Plano BR-163 Sustentável. Nesse processo, algumas formas de ação como os bloqueios de rodovia se fortaleceram, sendo justificados pelas injustiças.

Com a eleição de Bolsonaro, muitos identificaram um retorno ao tempo de antes da crise em termos da expectativa de progresso, renovada com o fim da pavimentação da BR-163. A intensificação do processo de devastação da Amazônia, que corrói institucionalidades ambientais e de direitos coletivos, acompanha assim a ambientalização dos conflitos, movendo contradições entre segmentos do povo da $B R-163$, ações críticas de agentes estatais (como o MPF) e pressões internacionais. 


\section{Referências}

Almeida, Alfredo Wagner Berno de, Joaquim Shiraishi Neto, e Cynthia Carvalho Martins. 2005. Guerra ecológica nos babaçuais: o processo de devastação dos palmeirais, a elevação do preço de commodities e o aquecimento do mercado de terras na Amazônia. São Luís: Lithograf.

Anderson, Benedict. 2008. Comunidades imaginadas: reflexões sobre a origem e a difusão do nacionalismo. São Paulo: Companhia das Letras.

Araújo, Rosane de Seixas Brito. 2007. "Vozes dissonantes: Estado, discurso e conflito no Oeste do Pará". Dissertação de mestrado, Universidade Federal do Pará, Belém.

Bailey, Frederick G. 1971. Gifts and Poison: The Politics of Reputation. Oxford: Basil Blackwell.

Barros, Ciro. 2019a. "'Desfaça tudo essas reservas', diz produtora a secretário em reunião de fazendeiros do Pará com governo federal”. Agência Pública, 22 abr. 2019. https://bit.ly/3Ecn5qo.

Barros, Ciro. 2019b. "Mortes, garimpo e grilagem assolam assentamento mais incendiado do Pará", 3 set. 2019. Agência Pública, 22 abr. 2019. https://bit.ly/32pPDPW.

Bemerguy, Telma de Sousa. 2019. "Notas sobre a feitura de um novo Estado na Amazônia Paraense: afetos e afetações em mobilizações sociais pelo Tapajós”. Amazônica 11 (2): 771-800.

Bemerguy, Telma de Sousa. 2021. "Etnografando estradas e caminhos da 'conquista': sobre a presença colonial e a gramática bolsonarista na Amazônia”. In Antropologia das mobilidades, orgs. Candice Vidal e Souza, e André Dumans Guedes, 179-213. Brasília: ABA.

Boltanski, Luc. 2004. Distant suffering: morality, media and politics. Cambridge: Cambridge University Press.

Camilo, Márcio. 2020. "Apoiados por Bolsonaro, garimpeiros fortalecem movimento pela legalização do garimpo no Pará”. O Estado de Mato Grosso, 23 mar. 2020. https://bit.ly/3qdprjM.

Campbell, Jeremy M. 2012. "Between the material and the figural road: The incompleteness of colonial geographies in Amazonia”. Mobilities 7 (4): 481-500.

Campbell, Jeremy M. 2015. Conjuring property: speculation and environmental futures in the Brazilian Amazon. Seattle: University of Washington Press.

Castro, Edna Maria Ramos de, Raimunda Monteiro, e Carlos Potiara Castro. 2004. Dinâmica de atores, uso da terra e desmatamento na rodovia Cuiabá-Santarém. Paper n. 119. Belém: UFPA.

Champagne, Patrick. 1984. "La manifestation. La production de l'événement politique”. Actes de la recherche en sciences sociales (52-53): 19-41.

Coelho, Maria Célia, Luiz Jardim Wanderley, e Reinaldo Costa. 2017. "Garimpeiros de ouro e cooperativismo no século XXI. Exemplos nos rios Tapajós, Juma e Madeira no Sudoeste da Amazônia Brasileira". Confins (33): 1-25.

Comerford, John. 1999. Fazendo a luta. Sociabilidade, falas e rituais na construção de organizações camponesas. Rio de Janeiro: Relume Dumará.

Cordeiro, Manuela Souza Siqueira. 2018. "Pioneiros, fundadores e aventureiros - a ocupação de terras em Rondônia”. Revista de Antropologia 61 (1): 125-46. 
Correa, Simy de Almeida, Edna Maria Ramos de Castro, e Sabrina Mesquita do Nascimento. 2013. "Política florestal e conflitos socioambientais na rodovia Cuiabá-Santarém (BR-163)". In Sociedade, floresta e sustentabilidade, Marcelo Sampaio Carneiro, Manuel Amaral Neto, e Edna Maria Ramos de Castro, 107-29. Belém: IIEB.

Coruja, Zé. 2004. Novo Progresso. Passado, Presente e Futuro. Novo Progresso.

Das, Veena. 1995. Critical events: an anthropological perspective on contemporary India. New Delhi: Oxford University Press.

Estudo de Impacto Ambiental BR-163. V. 5, Apêndice 3. Componente indígena, 2002.

Fleury, Lorena, Rômulo Barbosa, e Horácio Antunes de Sant’Ana Júnior. 2017. "Sociologia dos Conflitos Ambientais". Revista Brasileira de Sociologia 5 (11): 219-53.

Galuch, Mariana. 2019. "Do assentamento ao agronegócio: uma etnografia das migrações, políticas e dinâmicas territoriais em Apuí (Amazonas)”. Tese de doutorado, Universidade Federal do Amazonas, Manaus.

Garimpeiros interditam BR-163 para cobrar legalização de garimpos no sudoeste do Pará, G1, 9 set. 2019. https://glo.bo/30UDthl.

Glycerio, Carolina. 2008. "Crise alimentar vira argumento para produtores rurais", $B B C$ Brasil, 14 maio 2008. https://bbc.in/3iwCkQ3.

Gonçales, Nathalia Ferreira. 2021. "Um passado mal-acabado: políticas de rebaixamento étnico-racial da população cigana”. Anuário Antropológico 46 (3): 130-48.

Grupo de Trabalho Interministerial (GTI). 2005. Plano de Desenvolvimento Regional Sustentável para a Área de Influência da Rodovia BR-163 Cuiabá-Santarém: $2^{\mathrm{a}}$ Etapa de Consultas à Sociedade. Brasília: Casa Civil da Presidência da República.

Hage, Ghassan. 2009. "Waiting out the crisis: on stuckedness and governmentality". In Waiting, org. Ghassan Hage, 97-106. Carlton: Melbourne University Press.

Heredia, Beatriz Maria Alasia de. 1983. "Versões de uma crise: o caso do 'açúcar' no sul de Alagoas”. Boletim do Museu Nacional 46: 1-16.

Instituto Chico Mendes de Conservação da Biodiversidade. 2009. Estudo técnico de revisão dos limites da Floresta Nacional do Jamanxim: relatório final. Brasília, 30 set. 2009. https://bit.ly/3sCwYM3.

Instituto Chico Mendes de Conservação da Biodiversidade. 2010. Plano de Manejo da Floresta Nacional do Jamanxim, Pará. v. 2. Curitiba: ICMBio. Acesso 10 dez. 2021. https://bit.ly/3dlyuEV.

Instituto Nacional de Colonização e Reforma Agrária (Santarém). 2005. Processo 54501.000676/2005-02. Solicita criação de projeto em Cachoeira da Serra e Castelo dos Sonhos, Novo Progresso. Santarém: Incra.

Jasper, James. 2018. The emotions of protest. Chicago: The University of Chicago Press.

Lacerda, Paula. 2014. "O sofrer, o narrar, o agir: dimensões da mobilização social de familiares de vítimas”. Horizontes Antropológicos 20 (42): 49-75.

Lacerda, Renata. 2015. "Fazer movimentos: mobilidade, família e Estado no Sudoeste Paraense". Dissertação de mestrado, Universidade Federal do Rio de Janeiro, Rio de Janeiro.

Lacerda, Renata. 2019. "Brigar junto contra o governo: alianças e disputas na implantação de um plano de desenvolvimento sustentável”. RBCS 34 (100): 1-19.

Lacerda, Renata. 2021. "A cidade como forma de diferenciação: famílias pioneiras e fundadores na Amazônia". Wamon 6 (1): 69-89. 
Lacerda, Renata. 2022. Coragem para segurar a terra: habitação, trabalho e violência. No prelo.

Lambek, Michael. 2016. "The past imperfect: remembering as moral practice". In Tense past: cultural essays in trauma and memory, orgs. Paul Antze, e Michael Lambek, 298-318. New York: Routledge.

Leão, Andréa Simone Rente. 2017. "Na trilha da estrada: (des) caminhos do Plano BR-163 Sustentável como concepção do desenvolvimento na Amazônia”. Tese de doutorado, Universidade Federal Rural do Rio de Janeiro, Rio de Janeiro.

Leite Lopes, José Sérgio. 2006. "Sobre processos de 'ambientalização' dos conflitos e sobre dilemas da participação”. Horizontes Antropológicos (25): 31-64.

Manifestantes... 2013. "Manifestantes bloqueiam rodovia BR-163, em Novo Progresso, no PA", G1 PA, 5 out. 2013. https://glo.bo/3pfQ2NZ.

Ministério Público Federal. 2020a. MPF recomenda à ANM medidas contra a concentração ilegal de permissões de lavra garimpeira. 20 mar. 2020. https://bit.ly/2MF9Wl1.

Ministério Público Federal. 2020b. MPF recomenda ao Incra que retire grileiros invasores do assentamento Terra Nossa, no Sudoeste do Pará. 23 out. 2020. https://bit. ly/3q5Dzto.

Oravec, Gertrudes Strassburg. 2008. A saga dos pioneiros no município de Novo Progresso - Pará. Novo Progresso - Pará.

Pacheco de Oliveira, João. 2016. O nascimento do Brasil e outros ensaios: "pacificação", regime tutelar e formação de alteridades. Rio de Janeiro: Contracapa.

Pinheiro-Machado, Rosana. 2019. Amanhã vai ser maior: o que aconteceu com o Brasil e possiveis rotas de fuga para a crise atual. São Paulo: Planeta do Brasil.

Ribeiro, Reginaldo. 2011a. "População está revoltada com as atitudes dos índios Kayapó”. Blog O Atual, 15 set. 2011. https://bit.ly/3Fq5UDi.

Ribeiro, Reginaldo. 2011b. "BR - 163 Liberada - Em menos de 48 horas o governo atendeu os indígenas kayapó”. Blog O Atual, 18 set. 2011. https://bit.ly/3sk9z1E.

Santos, Nazareno. 2018. Seu Mané: ascensão e queda de um milionário no ciclo do ouro no Tapajós. Alta Floresta: Correa.

Schneider, Sara Royer, e Raquel Fortes. 2011. A história de Novo Progresso. Novo Progresso: Editora da UFPA.

Schumann, Charlotte, Korbinian Hartberger, Michael Klingler, e Regine Schonenberg. 2015. Sempre pra frente. Histórias de vida da BR 163. São Paulo: Olhares.

Seluchinesk, Rosane Duarte Rosa. 2008. "De heróis a vilões: imagem e auto-imagem dos colonos da Amazônia mato-grossense". Tese de doutorado, Universidade de Brasília, Brasília.

Seyferth, Giralda. 1992. "As contradições da liberdade. Análise das representações sobre a identidade camponesa”. RBCS 7 (1): 1-31.

Silva, Patrícia Guedes da. 2011. "Floresta Nacional do Jamanxim: mecanismo de ordenamento territorial e de desenvolvimento sustentável". Tese de doutorado, Universidade Federal do Pará, Belém.

Tarca, Karina. 2014. "Entre tempos bons e ruins. Processos de expansão e fechamento na fronteira amazônica: o caso de Cachoeira da Serra no sul do Pará". Dissertação [mestrado em Antropologia]. Niterói: Universidade Federal Fluminense.

Tarca, Karina. 2020. "Territorialidade, identidade e conflitos socioambientais no Sudo- 
este Paraense". In História: sujeitos, teorias e temporalidades, org. Willian Douglas Guilherme. Ponta Grossa: Atena.

Tedesco, Leticia de Luz. 2015. No trecho dos garimpos: mobilidade, gênero e modos de viver na garimpagem de ouro amazônica. Porto Alegre; Amsterdam: Universidade Federal do Rio Grande do Sul; VU Amsterdam.

Thompson, Edward Palmer. 1998. Costumes em comum. São Paulo: Companhia das Letras.

Torres, Maurício, e Sue Branford. 2017. "Amazônia ou parque dos dinossauros? Grileiros sentem ‘um ambiente bem mais positivo’ em Brasília e avançam para novas conquistas". The Intercept Brasil, 4 abr. 2017. https://bit.ly/3e1ehJb.

Torres, Maurício, Juan Doblas, e Daniela Fernandes Alarcon. 2017. Dono é quem desmata. Conexões entre grilagem e desmatamento no Sudoeste Paraense. São Paulo; Altamira: Urutu-branco; Instituto Agronômico da Amazônia.

Torres, Maurício. 2005. "Fronteira, um eco sem fim". In Amazônia revelada: os descaminhos ao longo da BR-163, org. Maurício Torres, 271-319. Brasília: CNPq.

Torres, Maurício. 2012. "Terra privada vida devoluta: ordenamento fundiário e destinação de terras públicas no Oeste do Pará". Tese de doutorado, Universidade de São Paulo. São Paulo.

Valente, Rubens. 2020. "Kayapós queimam ofício da Funai e dizem que órgão é 'inimigo' dos indígenas”. Uol, 20 ago. 2020. https://bit.ly/32rdnDs.

Weitzman, Rodica. 2022. No prelo (neste dossiê). 